\title{
Food Intake and Lipid Status of Three Vietnamese Populations with Different Incomes
}

\author{
NguYen Thi Lan Anh ${ }^{1}$, Tran Thanh Do ${ }^{1}$, Do Thi Kim Lien ${ }^{1}$, Ha Huy Khoi ${ }^{1}$, \\ NGUYEN Van Chuyen ${ }^{2}$ and Shigeru Yамамото ${ }^{3}$ \\ ${ }^{1}$ The National Institute of Nutrition, 48 Tang Bat Ho, Ha Noi, Vietnam \\ ${ }^{2}$ Department of Food and Nutrition, Japan Women's University, Tokyo 112-8681, Japan \\ ${ }^{3}$ Department of Applied Nutrition, The University of Tokushima, Tokushima 770-8503, Japan
}

(Received June 30, 2000)

\begin{abstract}
Summary In order to have basic data for dietary preventive measures against some vascular diseases caused by disorder of lipid metabolism, food intake and lipid status were investigated in three Vietnamese populations with different per capita income levels. Totally, 299 people aged over 18 were involved in this study. Among them, 98 subjects were selected from one commune with low income, 100 and 101 subjects from two urban areas with medium and high income respectively. Food intake was assessed by 24 -h recall method and lipid status was evaluated by measuring serum concentration of triglyceride, total cholesterol and its subfractions. The results showed that food consumption, dietary habits and lipid status varied with income levels. In general, diet was still unbalanced in all three groups, and low in fat and protein. In the rural, fat and protein intakes were lower than in the urban. The high prevalence of low serum cholesterol was observed in all three groups, the highest in the rural (45.3\%) and the lowest in the urban (11.2\%). On the contrary, the prevalence of high serum cholesterol was the lowest in the rural $(2 \%)$ and the highest in the urban $(16 \%)$. From these data, it is suggested that the majority of the Vietnamese might be vulnerable to some vascular diseases such as stroke if the situation of low fat intake and low serum cholesterol is not a problem of concern.
\end{abstract}

Key Words food intake, lipid status, cholesterol, stroke, Vietnamese

The annual statistics on nutrition of Vietnam reported by the National Institute of Nutrition of Vietnam (NIN) showed that the dietary intake and nutrition status of Vietnamese people have been improved (1). Concerning food intake, the energy intake reached the Recommended Dietary Allowance (RDA) for Vietnamese people proposed by NIN (2). However, their diet was still unbalanced, the energy intake was high in carbohydrate, low in fat and protein, especially in areas with low income. Meanwhile, the situation of cardiovascular disease induced by excessive fat intake in developed countries as well as the increase of myocardial infraction and cerebrovasccular accident cases in the central and provincial hospitals of Vietnam during recent years led to the fact that the majority of the population in the city have tried to minimize their own fat consumption. The reduction of salt and fat intake as well as using vegetable oil instead of animal fat, has been considered a healthy dietary habit to prevent cardiovascular disease in Vietnam.

It was well known that high fat consumption was the main cause of coronary heart disease and stroke through high cholesterol concentration as an intermediary factor in industrialized countries (3). On the contrary, stroke was attributable to low dietary fat via low serum cholesterol level in the case of Japan after the Second World War $(4,5)$.

In Vietnam, recently, dietary and disease patterns have been rapidly changing under the influence of the economic transition. Therefore, dietary risk factors for vascular diseases should be considered from two points of view: excess and insufficiency of fat intake. This study was carried out in order to assess food intake and lipid status of three Vietnamese populations representing different income levels. These basic data are intended for establishing dietary preventive measures against vascular diseases caused by disorders of blood lipid.

\section{METHODS}

Subject. This study was carried out in two subquarters of Hanoi, Cua Dong and Thanh Luong, and in Yen So commune of Hatay province. Cua Dong is a trading area located in the center of Hanoi. A large number of people living in Cua Dong are small traders. Average per capita income of Cua Dong is classified at high grade. Thanh Luong is an area of laborers with medium income, most of them are workers. Yen So is an agricultural commune $30 \mathrm{~km}$ south-east of Hanoi. The main income of Yen So people is still low, mostly based on rice cultivation. The nature of occupations of three study populations causes a difference in their physical activities. In Vietnam, industrial automation is still not developed so that the work of worker and farmer is of high physical activity. The trading business of subjects in Cua Dong is graded at medium or low level of physical activity. In each area, 36 households were randomly selected from the resident registered list provided by Local People's Committee. All members aged over 18 in 
these selected families were investigated.

Dietary assessment. Dietary intake was recalled and recorded on three consecutive days by staff-members of NIN. The intake of nutrients was calculated based on the Table of Food Composition of Vietnam (6).

Anthropology. Height in bare feet and weight in light clothing were measured. The Body Mass Index (BMI) was calculated as weight divided by the square of height $\left(\mathrm{kg} / \mathrm{m}^{2}\right)$. The nutrition status was assessed by BMI. Emaciation, overweight and obesity were defined as $\mathrm{BMI}<18.4,25.0 \leq \mathrm{BMI}<29.9$ and $\mathrm{BMI} \geq 30$ respectively (7). Blood pressure was measured by using a standard mercury sphygmomanometer on the right arm of subjects, who sat quietly at least 10 minutes. Hypertensives were defined as persons with systolic blood pressure $>160 \mathrm{mmHg}$ and/or diastolic blood pressure $>$ $95 \mathrm{mmHg}$ and/or taking antihypertensive medication.

Lipid status. The lipid status was assessed by fasting serum level of Total Cholesterol (TC), High Density Lipoprotein Cholesterol (HDL) and Triglyceride (TG) measured by colorimetric method. Low Density Lipoprotein Cholesterol (LDL) was estimated by Friedewald formula $(8)$ :

$$
\begin{aligned}
& \mathrm{LDL}(\mathrm{mg} / \mathrm{dL}) \\
& \quad=\mathrm{TC}(\mathrm{mg} / \mathrm{dL})-\mathrm{HDL}(\mathrm{mg} / \mathrm{dL})-\mathrm{TG}(\mathrm{mg} / \mathrm{dL}) / 5
\end{aligned}
$$

Statistical analysis. Data were expressed with both the mean and the standard deviation. One-way analysis of variance was followed by $\mathrm{F}$ test to compare the means of continuous variables and to evaluate significant differences between groups.

\section{RESULTS AND DISCUSSION}

\section{Nutritional status}

Results of nutritional status of three Vietnamese populations are shown in Table 1. The rural and the suburban areas had higher prevalence of emaciation while the urban area had a considerable increase of obesity. The trend that the prevalence of obesity increases with the rise of income level was also proved in a comparison of the nutrition status of three Vietnamese populations with that of the Japanese. The Vietnamese had a higher prevalence of emaciation, while obesity was a problem for the Japanese with high prevalence of $19.7 \%$ in male and $14.6 \%$ in female (9).

Prevalence of hypertension observed in the Vietnamese in this study was not high and was far lower than the prevalence in the Japanese investigated in 1995 , i.e., $19.1 \%$ in male and $13.4 \%$ in female (9). Food consumption and nutrient intake

Comparison of food consumption of three Vietnamese populations also showed the trend reported in survey on nutrition status of several Vietnamese populations after 10 years of economic transition 1985-1995. Together with the growth of household income, animal foods and ripe fruits have been increasingly consumed while rice has been less used. With higher income, Cua Dong people could improve their meals by consuming more meats, fish, eggs, milk, dairy products and ripe fruits than people in Yen So. In Vietnam, for those with low income, these foods are still not frequently consumed. Consumption of rice, vegetables, fat and oil of Thanh Luong and Yen So were significantly higher than that of Cua Dong. While people with medium or low income need fat and oil to prepare meals from vegetables, those with higher income try to reduce fat and oil in cooking in order to prevent some chronic diseases, so fat and oil consumption of Cua Dong was the lowest among three areas.

In general, the energy intake of three investigated populations nearly met the RDA for the Vietnamese. In Yen So, most people are farmers with high physical activity, they need higher total energy intake and protein intake than those living in urban areas. Actually, energy intake of Yen So people met allowance at medium and low level of physical activity for men and women respectively. Proportion of protein in total energy met RDA for the Vietnamese but animal protein intake was very low. Energy fat component in total energy was about $75 \%$ of RDA. Moreover, fat intake of Yen So people might be lacking some important polyunsaturated fatty acids contained in fish and vegetable oil because

\begin{tabular}{|c|c|c|c|c|c|c|}
\hline \multirow{2}{*}{ Variable } & \multicolumn{3}{|c|}{ Male } & \multicolumn{3}{|c|}{ Female } \\
\hline & Urban $n=49$ & Suburban $n=47$ & Rural $n=42$ & Urban $n=52$ & Suburban $n=53$ & Rural $n=56$ \\
\hline Age $(\text { year })^{1}$ & $49.7 \pm 17.4^{\mathrm{a}}$ & $44.4 \pm 15.6^{\mathrm{a}}$ & $39.5 \pm 14.7^{\mathrm{b}}$ & $48.9 \pm 16.4^{\mathrm{a}}$ & $44.4 \pm 17.1^{\mathrm{a}}$ & $39.7 \pm 14.8^{b}$ \\
\hline Weight $(\mathrm{kg})^{1}$ & $53.9 \pm 6.9^{\mathrm{a}}$ & $51.5 \pm 6.1$ & $49.9 \pm 5.7^{\mathrm{b}}$ & $51.2 \pm 8.6^{\mathrm{a}}$ & $48.3 \pm 7.7^{\mathrm{a}}$ & $43.7 \pm 4.4^{b}$ \\
\hline Height $(\mathrm{cm})^{1}$ & $162.1 \pm 6.2$ & $163.3 \pm 5.4$ & $160.7 \pm 6.0$ & $153.4 \pm 5.4^{\mathrm{a}}$ & $153.8 \pm 4.4^{\mathrm{a}}$ & $151.1 \pm 5.6^{\mathrm{b}}$ \\
\hline BMI $\left(\mathrm{kg} / \mathrm{m}^{2}\right)^{1}$ & $20.5 \pm 2.7^{\mathrm{a}}$ & $19.3 \pm 2.1^{b}$ & $19.3 \pm 1.7^{\mathrm{b}}$ & $21.7 \pm 3.2^{\mathrm{a}}$ & $20.4 \pm 3.0^{\mathrm{b}}$ & $19.1 \pm 1.7^{\mathrm{c}}$ \\
\hline $\mathrm{BMI}>25\left(\mathrm{~kg} / \mathrm{m}^{2}\right)^{2}$ & $6.1 \%$ & $2.1 \%$ & $0 \%$ & $17.3 \%{ }^{\mathrm{a}}$ & $9.4 \%$ & $1.8 \%{ }^{\mathrm{b}}$ \\
\hline $\mathrm{BMI}<18.4\left(\mathrm{~kg} / \mathrm{m}^{2}\right)^{3}$ & $16.3 \%$ & $34.0 \%$ & $30.9 \%$ & $15.3 \%$ & $26.4 \%$ & $28.6 \%$ \\
\hline Diastolic (mmHg) & $74.3 \pm 13.2$ & $71.7 \pm 10.5$ & $75.7 \pm 9.9$ & $72.0 \pm 10.6$ & $70.1 \pm 12.9$ & $71.4 \pm 15.8$ \\
\hline Systolic (mmHg) & $119.8 \pm 21.6$ & $121.6 \pm 23.4$ & $117.2 \pm 11.3$ & $116.4 \pm 17.1$ & $116.2 \pm 22.2$ & $113.6 \pm 23.3$ \\
\hline Hypertension $^{4}$ & $6.6 \%$ & $4.6 \%$ & $2.6 \%$ & $4.0 \%$ & $7.6 \%$ & $3.8 \%$ \\
\hline
\end{tabular}

Table 1. Nutritional characteristics of three Vietnamese populations.

${ }^{1}$ Data was shown as mean \pm SD.

${ }^{2,3}$ Percentage of subjects with BMI $>25\left(\mathrm{~kg} / \mathrm{m}^{2}\right)$ and with BMI $<18.4\left(\mathrm{~kg} / \mathrm{m}^{2}\right)$ respectively.

${ }^{4}$ Percentage of hypertensive subjects. Hypertension was defined in Method.

Value in a row for each sex with different superscript letters $(a-c)$ among three study areas were significantly different at $p<0.05$. 
Table 2. Food consumption of three Vietnamese populations.

\begin{tabular}{|c|c|c|c|c|c|c|}
\hline \multirow{2}{*}{$\begin{array}{c}\text { Variable } \\
\text { (g/capita/d) }\end{array}$} & \multicolumn{3}{|c|}{ Male } & \multicolumn{3}{|c|}{ Female } \\
\hline & Urban $n=49$ & Suburban $n=47$ & Rural $n=42$ & Urban $n=52$ & Suburban $n=53$ & Rural $n=56$ \\
\hline Rice and cereals & $465.7 \pm 135.0^{\mathrm{a}}$ & $496.1 \pm 167.8^{a}$ & $658.7 \pm 177.8^{b}$ & $408 \pm 155.4^{\mathrm{a}}$ & $457.5 \pm 151.3^{b}$ & $538.7 \pm 134.1^{b}$ \\
\hline Tubers & $2.1 \pm 14.5$ & $12.5 \pm 60.1$ & $5.4 \pm 24.5$ & $9.2 \pm 37.0$ & $6.7 \pm 34.3$ & $10.7 \pm 33.9$ \\
\hline Beans & $34.4 \pm 52.2$ & $53.8 \pm 92.7$ & $36.1 \pm 48.7$ & $27.2 \pm 50.1$ & $43.7 \pm 89.6$ & $35.3 \pm 58.6$ \\
\hline Vegetables & $137.0 \pm 71.4^{\mathrm{a}}$ & $222.7 \pm 108.4^{\mathrm{b}}$ & $266.9 \pm 142.4^{b}$ & $153.0 \pm 109.8^{\mathrm{a}}$ & $210.2 \pm 120.6^{b}$ & $203.7 \pm 117.0$ \\
\hline Fruits & $67.4 \pm 95.7^{\mathrm{a}}$ & $67.7 \pm 97.2^{\mathrm{a}}$ & $6.0 \pm 27.4^{\mathrm{b}}$ & $143.8 \pm 123.4^{\mathrm{a}}$ & $40.3 \pm 80.8^{b}$ & $20.3 \pm 70.8^{b}$ \\
\hline Fat and oils & $1.4 \pm 3.2^{\mathrm{a}}$ & $7.8 \pm 20.0^{\mathrm{b}}$ & $8.7 \pm 8.7^{\mathrm{b}}$ & $1.3 \pm 2.7^{\mathrm{a}}$ & $5.2 \pm 9.1^{\mathrm{b}}$ & $6.6 \pm 6.7^{\mathrm{b}}$ \\
\hline Meats & $144.6 \pm 90.6^{\mathrm{a}}$ & $122.0 \pm 84.0^{\mathrm{a}}$ & $70.5 \pm 81.2^{\mathrm{b}}$ & $115.4 \pm 80.6^{\mathrm{a}}$ & $119.0 \pm 79.4^{\mathrm{a}}$ & $39.5 \pm 51.7^{b}$ \\
\hline Fish and shellfish & $36.2 \pm 74.0^{\mathrm{a}}$ & $19.5 \pm 37.0$ & $8.5 \pm 29.6^{b}$ & $26.5 \pm 58.8$ & $19.1 \pm 40.1$ & $9.5 \pm 35.0$ \\
\hline Eggs & $17.5 \pm 25.8$ & $13.7 \pm 29.7$ & $8.8 \pm 25.9$ & $16.5 \pm 25.9^{\mathrm{a}}$ & $8.0 \pm 23.0$ & $4.1 \pm 11.8^{b}$ \\
\hline Milk \& dairy products & $12.1 \pm 51.0$ & $2.1 \pm 9.1$ & $0.4 \pm 3.0$ & $1.7 \pm 9.3$ & $4.8 \pm 20.0$ & $0.1 \pm 1.3$ \\
\hline Sugar \& confectionary & $2.7 \pm 7.8$ & $1.6 \pm 6.1$ & $3.2 \pm 8.2$ & $8.0 \pm 42.1$ & $3.5 \pm 9.7$ & $2.5 \pm 6.5$ \\
\hline
\end{tabular}

Data were shown as mean \pm SD. Values in each row for each sex with different superscript letters (a-c) among three study areas were significantly different at $p<0.05$.

Table 3. Daily nutrient intake, per capita, of three Vietnamese populations.

\begin{tabular}{|c|c|c|c|c|c|c|}
\hline \multirow{2}{*}{ Variable } & \multicolumn{3}{|c|}{ Male } & \multicolumn{3}{|c|}{ Female } \\
\hline & Urban $n=49$ & Suburban $n=47$ & Rural $n=42$ & Urban $n=52$ & Suburban $n=53$ & Rural $n=56$ \\
\hline Energy (kcal) & $1,894.7 \pm 515.0^{\mathrm{a}}$ & $2,065.2 \pm 564.7^{\mathrm{a}}$ & $2,626.9 \pm 660.9^{b}$ & $1,573.1 \pm 512.0^{\mathrm{a}}$ & $1,906.6 \pm 576.5^{b}$ & $2,069 \pm 452.4^{b}$ \\
\hline Protein $^{1}$ & $16.7 \pm 3.5^{\mathrm{a}}$ & $14.8 \pm 2.3^{\mathrm{b}}$ & $12.1 \pm 2.3^{\mathrm{c}}$ & $16.5 \pm 4.1^{\mathrm{a}}$ & $14.6 \pm 2.4^{\mathrm{b}}$ & $12.0 \pm 1.9^{\mathrm{c}}$ \\
\hline Fat $^{1}$ & $14.2 \pm 6.6^{\mathrm{a}}$ & $15.7 \pm 6.1^{\mathrm{a}}$ & $10.9 \pm 4.3^{b}$ & $11.8 \pm 4.5^{\mathrm{a}}$ & $16.0 \pm 6.9^{b}$ & $9.9 \pm 4.2^{\mathrm{c}}$ \\
\hline Carbohydrate $^{1}$ & $69.0 \pm 8.6^{\mathrm{a}}$ & $69.4 \pm 7.3^{\mathrm{a}}$ & $76.9 \pm 5.6^{\mathrm{b}}$ & $71.5 \pm 7.3^{\mathrm{a}}$ & $69.3 \pm 8.4^{\mathrm{a}}$ & $78.0 \pm 4.7^{\mathrm{b}}$ \\
\hline Animal protein ${ }^{2}$ & $44.2 \pm 15.0^{\mathrm{a}}$ & $34.1 \pm 17.4^{b}$ & $17.8 \pm 16.7^{\mathrm{c}}$ & $41.9 \pm 14.4^{\mathrm{a}}$ & $35.6 \pm 16.6^{\mathrm{a}}$ & $14.7 \pm 15.3^{\mathrm{b}}$ \\
\hline Animal fat ${ }^{3}$ & $70.4 \pm 19.5$ & $69.9 \pm 23.7$ & $63.5 \pm 16.6$ & $65.2 \pm 18.1^{\mathrm{a}}$ & $71.2 \pm 22.9^{\mathrm{a}}$ & $55.0 \pm 20.8^{b}$ \\
\hline Calcium (mg) & $711.9 \pm 1,117.8$ & $588.8 \pm 798.4$ & $512.5 \pm 156.9$ & $583.5 \pm 1,254.5$ & $5 \quad 503.1 \pm 737.9$ & $394.7 \pm 140.0$ \\
\hline Iron (mg) & $12.0 \pm 3.4^{\mathrm{a}}$ & $13.2 \pm 4.6^{\mathrm{a}}$ & $15.9 \pm 4.6^{\mathrm{b}}$ & $10.9 \pm 3.6$ & $11.8 \pm 4.9$ & $12.6 \pm 5.5$ \\
\hline Animal iron (mg) & $3.4 \pm 1.9^{\mathrm{a}}$ & $3.0 \pm 2.4$ & $1.9 \pm 2.7^{b}$ & $2.5 \pm 1.6^{\mathrm{a}}$ & $2.6 \pm 2.3^{\mathrm{a}}$ & $1.2 \pm 2.4^{\mathrm{b}}$ \\
\hline $\operatorname{Vitamin} \mathrm{A}(\mu \mathrm{g})$ & $142.8 \pm 216.4$ & $180.5 \pm 504.4$ & $181.9 \pm 585.0$ & $115.0 \pm 171.2$ & $123.7 \pm 457.6$ & $133.8 \pm 605.8$ \\
\hline Vitamin B1 (mg) & $1.4 \pm 0.5$ & $1.34 \pm 0.48$ & $1.2 \pm 0.4$ & $1.37 \pm 0.59^{\mathrm{a}}$ & $1.3 \pm 0.6^{\mathrm{a}}$ & $1.1 \pm 0.4^{\mathrm{b}}$ \\
\hline Vitamin B2 (mg) & $0.8 \pm 0.3$ & $0.8 \pm 0.4$ & $0.8 \pm 0.4$ & $0.67 \pm 0.24$ & $0.7 \pm 0.4$ & $0.6 \pm 0.4$ \\
\hline Vitamin C (mg) & $53.8 \pm 44.7^{\mathrm{a}}$ & $53.0 \pm 32.7^{\mathrm{a}}$ & $95.6 \pm 79.9^{b}$ & $69.8 \pm 48.8$ & $47.1 \pm 37.9^{a}$ & $79.7 \pm 78.1^{b}$ \\
\hline
\end{tabular}

${ }^{1}$ Percentage of the nutrient against total energy.

${ }^{2}$ Percentage of animal protein against total protein.

${ }^{3}$ Percentage of animal fat against total fat.

Data were shown as mean \pm SD. Values in a row for each sex with different superscript letters $(a-c)$ among three study populations were significantly at $p<0.05$.

Table 4. Serum lipid concentrations of three Vietnamese populations.

\begin{tabular}{|c|c|c|c|c|c|c|}
\hline \multirow{2}{*}{ Variable } & \multicolumn{3}{|c|}{ Male } & \multicolumn{3}{|c|}{ Female } \\
\hline & Urban $n=49$ & Suburban $n=47$ & Rural $n=42$ & Urban $n=52$ & Suburban $n=53$ & Rural $n=56$ \\
\hline $\mathrm{TC}(\mathrm{mg} / \mathrm{dL})^{1}$ & $184.6 \pm 38.1^{\mathrm{a}}$ & $178.1 \pm 36.2^{\mathrm{a}}$ & $144.5 \pm 33.9^{b}$ & $182.1 \pm 42.3^{\mathrm{a}}$ & $182.8 \pm 41.4^{\mathrm{a}}$ & $142.6 \pm 28.5^{b}$ \\
\hline $\mathrm{HDL}(\mathrm{mg} / \mathrm{dL})^{1}$ & $43.6 \pm 7.6^{\mathrm{a}}$ & $48.83 \pm 12.8^{b}$ & $39.9 \pm 9.0^{\mathrm{a}}$ & $42.78 \pm 5.9^{\mathrm{a}}$ & $48.20 \pm 10.9^{b}$ & $40.19 \pm 6.1^{\mathrm{a}}$ \\
\hline $\mathrm{LDL}(\mathrm{mg} / \mathrm{dL})^{1}$ & $99.9 \pm 33.3^{\mathrm{a}}$ & $96.6 \pm 24.9^{\mathrm{a}}$ & $75.8 \pm 21.8^{\mathrm{b}}$ & $103.8 \pm 35.7^{\mathrm{a}}$ & $101.2 \pm 34.3^{\mathrm{a}}$ & $78.8 \pm 21.6^{b}$ \\
\hline $\mathrm{TG}(\mathrm{mg} / \mathrm{dL})^{1}$ & $205.1 \pm 120.4^{\mathrm{a}}$ & $163.3 \pm 99.2$ & $143.9 \pm 101.6^{\mathrm{b}}$ & $177.2 \pm 122.4^{\mathrm{a}}$ & $148.5 \pm 89.2$ & $117.9 \pm 89.8^{b}$ \\
\hline TC/HDL ratio ${ }^{1}$ & $4.2 \pm 0.8$ & $3.7 \pm 0.8$ & $3.7 \pm 1.0$ & $4.3 \pm 1.1^{\mathrm{a}}$ & $3.9 \pm 1.5$ & $3.6 \pm 0.8^{\mathrm{b}}$ \\
\hline $\mathrm{TC}>220 \mathrm{mg} / \mathrm{dL}^{2}$ & $13 \%$ & $8.5 \%$ & $2.4 \%$ & $7.8 \%^{\mathrm{a}}$ & $17 \%^{\mathrm{a}}$ & $0 \%{ }^{b}$ \\
\hline $\mathrm{TC}<140 \mathrm{mg} / \mathrm{dL}^{3}$ & $6.6 \%^{\mathrm{a}}$ & $17 \%^{\mathrm{a}}$ & $43.9 \%{ }^{b}$ & $19.6 \%^{\mathrm{a}}$ & $13 \%{ }^{\mathrm{a}}$ & $46.4 \%^{b}$ \\
\hline
\end{tabular}

TC: Total Cholesterol, HDL: High Density Lipoprotein Cholesterol, LDL: Low Density Lipoprotein Cholesterol, TG: Triglyceride.

${ }^{1}$ Data was shown as mean \pm SD.

${ }^{2,3}$ Percentage of subjects with total cholesterol $>220 \mathrm{mg} / \mathrm{dL}$ and $<140 \mathrm{mg} / \mathrm{dL}$ respectively.

Values in a row for each sex with different superscript letters $(a-c)$ among three study populations were significantly different at $p<0.05$. 
Male

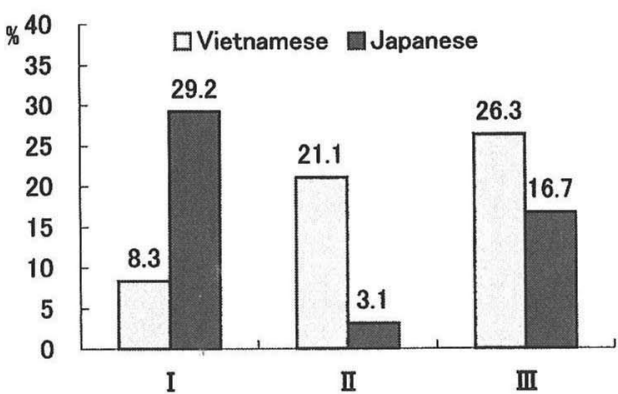

Female

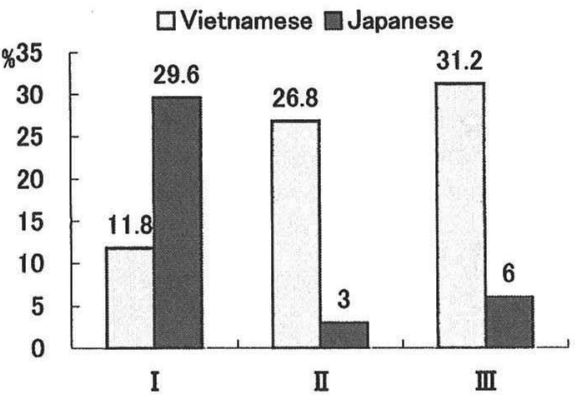

Fig. 1. Percentage of Vietnamese and Japanese with High and Low Serum Cholesterol Level (I: Serum cholesterol $\geq$ 220 mg/dL, II: Serum cholesterol $\leq 140$ mg/dL, III: Serum HDL-cholesterol $\leq 40$ mg/dL).

their consumption of these foods was very low. In Yen So as well as in other rural areas, pork might be the major protein and fat source, because, pork is the cheapest meat and fat in Viet Nam. The use of vegetable oil is not common in the countryside.

In the urban areas, the diet was improved with more proper energy proportion of protein, fat and carbohydrate. Proportion of protein in total energy met the RDA and animal protein intake was higher than that of the rural area. Energy contribution of fat in total energy intake also increased. In Cua Dong, fat intake of women was quite low. It can be explained by the dietary habits of women with higher income, avoiding food with high fat and sugar. During recent years, vegetable oil has been increasingly replacing fat in cooking in the city. By consuming more fish and vegetable oil, dietary fat intake of these two areas might contain more polyunsaturated fatty acids than the fat intake of Yen So people.

In all three Vietnamese populations, rice consumption was three or four times as much as the amount consumed by the Japanese (167.9 g per capita per d) (9). Other cereals such as corn and wheat are less used in Vietnam. Tubers are consumed much only when loss of rice crop occurrs as a result of damage from natural disaster. Despite the considerably higher amount of wheat (93.7 $\mathrm{g}$ per capita per d), potato and sweet potato ( $68.9 \mathrm{~g}$ per capita per d) used by the Japanese (9), totally, the Vietnamese still had higher starch consumption. Therefore, the proportion of carbohydrate energy in total energy of the Vietnamese was higher than that of the Japanese (male 58.6\% and female 56.8\%) (9). Energy component contributed by fat intake of the Vietnamese was much lower than that of the Japanese (male 25.7\% and female 27.1\%) (9). Moreover, with lower consumption of vegetable oil, fish and eggs, the fat intake of the Vietnamese must have contained less $n$ 6 and $n-3$ PUSA than the fat intake of the Japanese. A high carbohydrate and low fat intake like that of the rural people in this study was observed in the Japanese in 1950s and early 1960s, after the Second World War (10). The high prevalence of stroke was shown to be attributable to low fat intake in Japan during that time $(4,5)$

Concerning micronutrients, vitamin A intake of the three Vietnamese populations was significantly lower than that of the Japanese. This difference might be due to the low animal food intake and poor absorption of fat soluble vitamins affected by the lower fat intake of the Vietnamese.

Lipid status

The average concentrations of serum total cholesterol, HDL and LDL of all three populations were at normal levels, significantly lower in the rural than the urban areas. The prevalence of serum cholesterol above $220 \mathrm{mg} / \mathrm{dL}$ was highest in the urban while cholesterol level below $140 \mathrm{mg} / \mathrm{dL}$ was highest in the rural.

The average serum total cholesterol, HDL and LDL levels were higher in the Japanese than in the Vietnamese. The percentage of high serum cholesterol concentration for the Vietnamese was rather lower (male $8.2 \%$, female $11.8 \%$ ) than that of the Japanese (male $15.6 \%$, female $20.9 \%$ ). In both sexes, the percentage of low serum total cholesterol for the Vietnamese was high (male 21\%, female 26.8\%) compared to their Japanese counterparts (male $2.9 \%$ and female $1.5 \%$ ) (9).

High blood cholesterol was well demonstrated as the main risk factor in some vascular diseases (3). However, it is not reasonable to consider low blood cholesterol level as a protective determinant against these diseases. An inverse relationship between plasma cholesterol concentration and cerebral hemorrhage has been evidenced in a rural community of Japan (11). This occurrence might be explained by the mechanism based on the role of cholesterol in cell membrane. In the case of low blood cholesterol, vessel wall becomes weakened and is easily damaged especially under high pressure of blood stream. This pathogenesis mostly occurs in cerebral vessel, leading to brain hemorrhage.

Both high and low levels of blood cholesterol were also confirmed in ischemic cerebrovascular diseases, the most common clinical type accounting for up to $80 \%$ of stroke. While positive association between blood cholesterol and cerebral infarction was observed in the US and Europe (12), inverse correlation was affirmed in Japan (5). Two opposite trends might be explained by different effects of serum cholesterol level at different vascular sites. Epidemiological studies showed that, in 
the US and Europe cerebral infarction occurred much more frequently in cortical than penetrating artery region and it was positively associated with hypercholesterolemia (13). In Japan, cerebral infarction in penetrating artery regions was the most prevalent subtype of infarction and inversely related to serum cholesterol level (11). Low prevalence of cerebral infarction in cortical artery region of the Japanese is probably due to thrombosis formation inhibited by various physiologic effects of $n$-3FA (13). This fatty acid decreases platelet aggregation and blood viscosity and increases fibrinolytic activity (14-16). With high consumption of fish, the Japanese have higher $n$-3FA intake than the Americans and Europeans.

The heterogeneous pathogenesis of stroke related to disorders of blood cholesterol observed in the US, Europe and Japan might be valuable experiences for Vietnam to control this disease in the period of economic transition followed by the changing of dietary habits and lifestyle. This study was carried out in three populations representing different income levels. It showed that low fat intake and low blood cholesterol level were common in all three areas. The lipid intake of Yen So people was as low as that of the Japanese in the 1960s when Japan had the highest mortality from stroke among developed countries (17). In Vietnam, therefore, stroke is now a health problem not only for people with a westernized lifestyle in the city but also for people whose dietary intake is low in fat and protein, mostly in the countryside. In order to control stroke in Vietnam, both risk groups with low and high serum cholesterol levels should be soon concerned.

The brain cells damaged by infarction and hemorrhage are unable to repair themselves and only form fibrinolytic scar tissue. Therefore, the most effective therapy for stroke is prevention. Proper nutrition regime will contribute an effective measure to reduce stroke risk caused by both high and low blood lipid level. The decline of brain hemorrhage of a population in the northeastern of Japan from 1960 to 1990 was possibly due to serum cholesterol level elevated by the increase of fat intake (18). In order to protect the Vietnamese from stroke, fat consumption should be qualitatively and quantitatively improved. Allowance of fat as well as other nutrients should be recommended at both physiological requirement and safety level. This solution will help people to be properly aware the role of essential nutrients and to avoid both high and low consumption. Nutrition education should be established in detail, suitable for numerous vulnerable populations because social polarization is strongly underway in the period of economic transition. In conclusion, the result of this study showed that fat intake and lipid status of Vietnamese people differ with income level. People with low income consumed less fat and had lower serum cholesterol levels than those with high income. With low fat intake and high prevalence of hypocholesterolemia, stroke might be a health problem for Vietnamese. In order to prevent cardiovascular disease, especially stroke, dietary preventive measures should be undertaken.

\section{REFERENCES}

1) Khoi HH. 1996. Problems of nutrition in the transition period in Vietnam. Medical Publishing House, Hanoi (in Vietnamese).

2) Ministry of Health, The National Institute of Nutrition, Vietnam. 1997. The Table of Recommended Dietary Allowance for the Vietnamese. Medical Publishing House (in Vietnamese).

3) Willett W. 1990. Nutritional Epidemiology, Oxford University Press, New York.

4) Seino F, Date C, Nakayama T, Yoishike N, Yokoyama T, Yamaguchi M, Tanaka H. 1997. Dietary lipids and incidence of cerebral infarction in a Japanese rural community. J Nutr Sci Vitaminol 43: 83-99.

5) Tanaka H, Ueda Y, Hayashi M, Date C, Baba T, Yamashita H, Shoji H, Tanaka Y, Owada K, Detels R. 1982. Risk factors for cerebral hemorrhage and cerebral infarction in a Japanese rural community. Stroke 13: $62-72$.

6) Giay T, So PV, Thuan BTN, Duc BM. 1972. Table of food composition of Vietnam. Medical Publishing House, Hanoi (in Vietnamese).

7) James WPT, Ferro-Lzzia, Waterlow TC. 1988. Definition of chronic energy deficiency in adults. Eur J Clin Nutr 42: 969-981.

8) Friedewald WT, Levy RI, Fredrickson DS. 1972. Estimation of the concentration of Low Density Lipoprotein Cholesterol in plasma, without use of the preparative ultracentrifuge. Clin Chem 18: 499-502.

9) Ministry of Health and Welfare, Japan. 1997. National Nutrition Survey 1995. Daiichi Shuppan Publisher, Tokyo (in Japanese).

10) Yoshiike N, Matsumura $Y$, Iwaya M, Sugiyama M, Yamaguchi M. 1995. National nutrition survey in Japan. J Epidemiol 6: S189-S200.

11) Konishi M, Iso $H$, Komachi $Y$, Iida $M$, Shimamoto $T$, Jacobs D, Terao A, Baba S, Sankai T, Ito M. 1993. Association of total serum cholesterol, different type of stroke, and stenosis distribution of cerebral arteries: The Akita Pathology Study. Stroke 24: 954-964.

12) Dawber TR. 1980. The Framingham Study, The Epidemiology of Atherosclerotic Disease, Harvard University Press, London, p 121-141.

13) Kuller L, Reisler D. 1971. An explanation for variations in distribution of stroke and arteriosclerotic heart disease among populations and racial groups. Am J Epidemiol 93: 1-9.

14) Honstra G, Lussenberg RN. 1975. Relationship between the type of dietary fatty acid and the arterial thrombus tendency in rats. Atherosclerosis 22: 499516.

15) MacIntyre DE, Hoover RL, Smith M, Steer M, Lynch C, Karnovsky MJ, Salzman EW. 1984. Inhibition of platelet function by cis-unsaturated fatty acids. Blood 63: $848-857$.

16) Ulbricht TLV and Southgate DAT. 1991. Coronary heart disease: seven dietary factors. Lancet $\mathbf{3 3 8}$ : 985-992.

17) Tanaka H, Yamaguchi M, Date C, Nakayama $T$, Yamamoto T, Yoshiike N, Iwaya M, Matsumura Y, Yokoyama T, Noji A, Kushiro W, Cho BM. 1992. Nutrition and cardiovascular disease, a brief review of epidemiological studies in Japan. Nutr Health 8: 107123.

18) Shimamoto $\mathrm{T}$, Iso $\mathrm{H}$, Tanigawa $\mathrm{T}$, Sankai $\mathrm{T}$, Imano $\mathrm{H}$, Ohira T, Miyake S. 1996. Trend for cardiovascular risk factors and diseases in Japan. J Epidemiol 6: S183S188. 